\title{
Writing the Journal Article
}

\begin{abstract}
In their writing for publication, librarians have not adequately exploited journals in many fields that may be open to them and so have not done an adequate job of advancing library interests. Although few librarians have taken advantage of the opportunity to write for publication, there are a number of incentives present to encourage them. Guidelines are offered on writing for publication: selection of the journal for submission and mechanics related to article preparation.
\end{abstract}

$T_{1}$ HE UNITED States is a nonfiction writer's paradise. The over 22,000 periodicals published in the United States today represent an insatiable market for nonfiction. Never has there been such a demand for magazine articles. In library and information science alone there are many, many journals, issued at the national, regional, and state levels and by individual libraries. The list grows even longer when one adds to that number those of peripheral interest to librarians, such as those in personnel management, education, communications, media, and computer science.

Librarians have not developed that potential market. As far as considering possibilities for publishing articles, the profession has become very inward-looking. Only a few articles, written about libraries and librarians, by librarians have had an impact on nonlibrarian readers. For instance, look at the furor that Daniel Gore's article on the status

Robert D. Stueart is dean, School of Library Science, Simmons College, Boston, Massachusetts. This article is based on an address given at the Conference on Writing and Publishing for Librarians, sponsored by the New England Chapter of the Association of College and Research Libraries in Waltham, Massachusetts, on April 4, 1975. of librarians had a few years ago when it was published in the AAUP Bulletin. ${ }^{1}$ Some hurriedly rushed to the defense of librarianship by publishing rebuttals.

However, if some librarian had already written a different version, the sensationalism of Gore's article would not have been nearly so great; and the defense would not have been necessary. Or look at his recent article on the growth of college libraries, which was published in College Management. ${ }^{2}$ Again our defenses are down because it appeared in a nonlibrary journal and is addressed primarily to a nonlibrarian audience. Jesse Shera, on the other hand, is one who has been able to defend library policy in the nonlibrary press. His article, in response to a physicist's plea for branch libraries, is a classic example of the impact librarians can have on a wider community. ${ }^{3}$ Yet very few librarians think further than the library press. A recent letter in the March 1974 issue of College \& Research Libraries by Anabel Sproat points out that in the comprehensive "Bibliography on Faculty Status," published in College \& Research Libraries, only two articles are cited from teaching journals; all others are from library journals. ${ }^{4}$ Other studies have reached similar 
conclusions. An important aspect that is being overlooked, then, is contact with the outside world. No one, except the librarian, has time or perhaps the inclination to read library literature.

Surely there are a number of areas of librarianship which are of interest to a much wider audience. We are all familiar with Winslow Hatch's description of a university or college library which goes something like this: "While the library is typically described as the heart of the campus, it is often more like the liver for it is a large structure whose significance lies in the potential it may not be called on to release." Part of the reason we are not called on is that we have not done an adequate selling joba public relations job-much of which can easily be accomplished through publication.

\section{LIBRARIANS AS AUTHORS}

Wolfgang Freitag's article on librarians as literary authors indicates that the librarian administrator who is also an active leading scholar in a major field of learning has virtually vanished. ${ }^{5}$ To take its place we should infiltrate the general academic scholarly periodical literature with our writing on librarianship.

Other people certainly write in library journals. Look at American Libraries and the large number there. A recent study of articles appearing in PNLA Quarterly indicated that 27 percent of the articles in the Quarterly were written by nonlibrarians. Of those which were by librarians, 64 percent were by academic librarians. ${ }^{6}$ This raises another question: Are academic librarians more prolific than others, and if so, why? Is it because of the publish or perish syndrome? Are salaries, status, and promotion dependent on publishing? In many institutions where librarians have faculty status, they have been forced to meet this publishing requirement. Perhaps more would publish if it were clearly understood that it is expected of them. It has been suggested that if this happened library science periodicals would proliferate. Is that a bad thing in itself? Couldn't the academic environment likewise have an effect on the quality of publications?

What really creates the climate to publish? Here are a number of elements to consider:

1. Do you want to publish? Is your idea something that has not been covered in the literature before?

2. Do you have to publish in order to advance professionally?

3 . Are you anxious to relate the results of research performed in a scientific manner?

4. Do you have a real commitment to writing, and have you made the distinction between scholarly research and "how to do it" articles? There is a place for both in the literature.

\section{The Pressures to Publish}

If you are in the publish or perish situation, perhaps the next question becomes: "What sort of released time is given for individual research and writing?" This is certainly a problem for academic librarians.

In a 1958 study by Kellum and Barker 78 percent of seventy-two libraries surveyed said that time was allowed for staff members to prepare articles, though a few administrators stated that they also expect writers to work on their own time as well. ${ }^{7}$ Seven out of eight of those library administrators give some kind of recognition for writing and publishing. A comparable study by Jesse and Mitchell of fifty-two ARL libraries and fifteen liberal arts colleges indicated that over half of the libraries al- 
lowed released time and that some provided clerical assistance and free photocopying. ${ }^{8}$ Despite that, only about 8 per cent of the 2,523 university librarians and 14 percent of the 106 college librarians had taken advantage of the opportunity in the previous three years. Is that because the interest was not there or because they didn't know how to begin? By far the most common action taken by administrators and committees in regard to librarians' publishing was in recommending advancement in rank or salary or in recommending tenure. But even if that incentive is not there, we all know that we find time for what we really want to do; it is simply a matter of establishing priorities. If writing has a high priority, then we write. After that it's contagious.

Another factor to consider is the continuing education aspect of writing in library-related areas. A point often overlooked is the one that Jim Matarazzo made in a speech to the Long Island Special Libraries Association Group, in which he maintained that professional literature can be used as a source of continuing education and is, in fact, the primary source of continuing education for most professionals. We should all have a commitment to this aspect, whether we are library educators or practicing librarians.

The recent study prepared for the National Commission on Libraries and Information Science on continuing education proposes a cassette service which would review and record outstanding articles, the idea being that librarians would be better able to keep up-to-date with what's going on by listening. ${ }^{9}$ However, one could question whether we would listen any more than we read. In writing, one should keep that in mind and look closer at the quality of one's own writing. This would help editors a great deal.
In 1915 Dr. Abraham Flexner stated that "the evolution toward professional status can be measured by the quality of publication set forth."10 This, then, is a measure for our writings.

\section{Technical Aspects of Writing JOURNAL ARTICLES}

If you are writing for the first time, you must decide whether you are going to aim at the big market, such as $\mathrm{Li}$ brary Journal, American Libraries, or AAUP Bulletin, or at a smaller audience, first, such as a state or regional journal. There are many smaller, quality journals which don't receive the same number of manuscripts as do the large ones. The Illinois, California, and Wisconsin state publications are good examples of this kind of journal. Perhaps that's a good place to begin. Very few professional journals these days, even including the large ones, can pay for articles published. This is one major difference between writing for a professional journal and writing for a more commercial one.

One should be prepared for, but not discouraged by, rejection notices or suggestions that the manuscript be rewritten or submitted to another journal. Often what is the right article for one publication may not be right-subject, length, etc.-for another. Sometimes the editor may feel the article has a good theme but that the writing or documentation needs to be tightened. In those cases the editor will often make suggestions.

There seem to be several steps in the manuscript writing process:

Identifying the subject: Do you have anything to say that has not been said before? Think seriously about this. Surely there are enough new things, new ideas, new philosophies emerging that one doesn't necessarily have to rehash a topic. Do a little search in the area: 
What special knowledge do you possess? Remember the search may start in the materials found in libraries; but field research, or applied research, is just as important. Once you have selected the idea, do some basic searching to establish that there is ample material available for a worthwhile article. Use upto-date material in your research, unless it's a historical paper. Nothing is more frustrating to a reader than to see outof-date statistics or citations being used to substantiate arguments.

Reaching the audience: The aim of writing is communication. You should not waste your time if there is no market for your ideas.

Structure and form are important: Establish what you want the article to say, and prepare an outline of your material so that the article will do what you intend it to do. The organization should capture the reader's interest; give direction to the article; report evidence to support the points being made; and make the reader feel well repaid for having read it.

Philip G. Becker in his tongue-incheek article indicates that an article should have four sections: the introduction, the main body, the summary, and the conclusion. Most importantly, the body occupies itself with a discussion of the theme of the article; and the author can do a magnificent job when the mind is set to it. For instance, the theme of an article might be: "The more books you have, the bigger the library collection." In ordinary writing, perhaps, the meaning of this statement would be relatively clear. However, an author might find that it was a little too clear. This is indicated by the opening paragraph. Becker concludes by saying: "In dealing with the administrative difficulties inherent in problems of this nature, it is essential to bear in mind that the organizational and administra- tive capacity of the library is governed in a directly proportioned manner by the amount of material which the library has collected by means of its acquisitional policy, through gifts and exchanges, as well as through normal acquisitional channels."11 Enough said.

Development of the article prepares the reader to understand how all parts hang together as a whole. The summary, as a final element, can answer this question. Someone said the summary is a recording of what you've written in an effort to determine what you've said; and one often finds that nothing has been said at all.

Finally, one must check the tone of the article-tone being style, grace, wit, anger, condescension, etc.

\section{ConcLusion}

Writing the first few articles is not easy. It becomes easier for someone who enjoys writing and who has written enough to have developed a sound technique. This is where the difference between an amateur and a professional begins to show. When the beginning writer completes the first draft, the author reads it through to correct typographical errors and considers the job done. When the professional writer completes the first draft, that is usually just the beginning of the writing process. The difference in attitude is the difference between amateur and professional.

A final warning is that writers must protect themselves from their own egos, whether in the form of uncritical pride or uncritical self-destruction. As poet John Ciardi once said: "The last act of writing must be to become one's own reader. It is, I suppose, a schizophrenic process, to begin passionately and to end critically, to begin hot and to end cold; and, more important, to be passion-hot and critic-cold at the same time." 


\section{REFERENCES}

1. Daniel Gore, "The Mismanagement of College Libraries: A View from the Inside," AAUP Bulletin 52:46-51 (Spring 1966).

2. Daniel Gore, "Zero Growth for the College Library," College Management 9:12-14 (Aug. 1974).

3. J. H. Shera, "How Much is a Physicist's Inertia Worth?" Physics Today 14:42-43 (Aug. 1961).

4. "Letters," College \& Research Libraries 35: 133 (March 1974).

5. Wolfgang M. Freitag, "The Proper Study of Librarians-What is it?" The Harvard Librarian 9:4-7 (Sept.-Oct. 1974).

6. Joann Scheck, "The Writing Librarian," PNLA Quarterly 34:23-25 (April 1970).

7. W. Porter Kellum and Dale L. Barker, "Activities and Opportunities of University Librarians for Full Participation in the Ed- ucational Enterprise," College \& Research Libraries 29:195-99 (May 1968).

8. William H. Jesse and Ann E. Mitchell, "Professional Staff Opportunities for Study and Research," College \& Research Libraries 29:87-100 (March 1968).

9. Continuing Library and Information Science Education: Final Report to the $\mathrm{Na}$ tional Commission on Libraries and Information Science (Washington, D.C.: American Society for Information Science, 1974).

10. Abraham Flexner, "Is Social Work a Profession?" School and Society 1:901-11 (June 26, 1915).

11. Philip G. Becker, "How to Write Effectively for a Library Periodical," in J. D. Marshall, ed., Of, By, and For Librarians (Hamden, Conn.: Shoe String, 1960), p. 302-4. 